
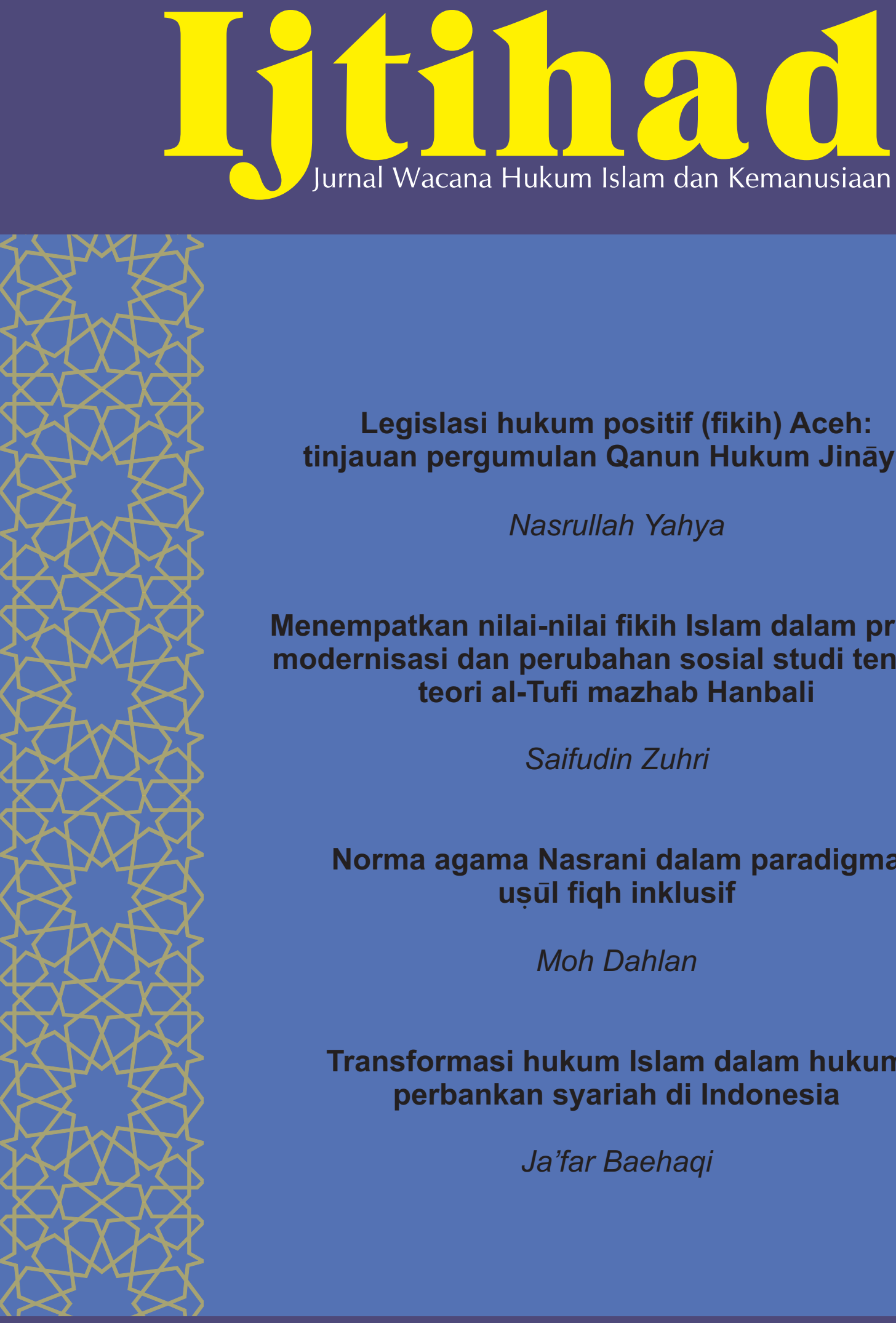

Legislasi hukum positif (fikih) Aceh: tinjauan pergumulan Qanun Hukum Jināyāh

\author{
Nasrullah Yahya
}

Menempatkan nilai-nilai fikih Islam dalam proses modernisasi dan perubahan sosial studi tentang teori al-Tufi mazhab Hanbali

Saifudin Zuhri

Norma agama Nasrani dalam paradigma ușūl fiqh inklusif

Moh Dahlan

Transformasi hukum Islam dalam hukum perbankan syariah di Indonesia

Ja'far Baehaqi 


\section{Ijtihad \\ Vol. 14, No. 2, Desember 2014}

\section{Daftar isi}

Legislasi hukum positif (fikih) Aceh: tinjauan pergumulan Qanun Hukum Jināyāh

Nasrullab Yabya • 149-166

Menempatkan nilai-nilai fikih Islam dalam proses modernisasi dan perubahan sosial studi tentang teori al-Tufi mazhab Hanbali

Saifudin Zubri • 167-187

Norma agama Nasrani dalam paradigma uṣūl fiqh inklusif

Mob Dablan • 189-209

Transformasi hukum Islam dalam hukum perbankan syariah di Indonesia Ja'far Baehaqi • 211-230

Akar, posisi, dan aplikasi adat dalam hukum

Abwan Fanani - 231-250

Bayang-bayang teori keagenan pada produk pembiayaan perbankan syariah Misnen Ardiansyah • 251-269

Dimensi politik hukum dalam perkembangan ekonomi Islam di Indonesia Bambang Iswanto • 271-284

Book Review:

Kritik otoritas pemaknaan hadis menuju masyarakat Islam berkemajuan Mubammad Irfan Helmy • 285-297 



\title{
Legislasi hukum positif (fikih) Aceh: tinjauan pergumulan Qanun Hukum Jināyāb
}

\author{
Nasrullah Yahya \\ STAIN Malikussaleh Lhokseumawe \\ Jl. Banda Aceh-Medan Km. 275 No. 1 Buket Rata-Alue Awe Lhokseumawe. Kode Pos 24352 \\ E-mail:nasrullah_arull@yahoo.com
}

This article aims to describe the background of the struggle that occurs in the design draft of Qanun Law Jinâyat between the camps of scholars and civilian camps. This occurs because the heated debate in the Qanun contains stoning an adulteress muhṣan in one of the article contents, so the legislation Qanun Law Jināyāt as positive law (fiqh) Aceh impact stagnation after it was enacted. Then discussed and passed back after repeated revisions by the abolition of stoning law provisions. The method used is qualitative-phenomenological research with the historical approach. The results showed that includes stoning an adulteress muḥsan Qanun Law Jināyah not contradict the hadith texts, and this has been agreed upon by the scholars. Terms of stoning also does not violate human rights, but including the goal of Personality '(māqāsid al-Shari'ah) in the determination of the law, which is for the benefit of humans, in order to protect offspring (hịiẓ al-nasl) as fulfillment ḍarūriyyah (primary) of mafsadat.

Artikel ini bertujuan untuk mendeskripsikan latar belakang lahirnya pergumulan yang terjadi pada draft rancangan Qanun Hukum Jināyah, yaitu antara kubu ulama dan kubu sipil. Perdebatan hangat ini terjadi karena dalam Qanun ini memuat hukum rajam bagi pezina muḅan dalam salah satu isi pasalnya, sehingga legislasi Qanun Hukum Jināyah sebagai hukum positif (fikih) Aceh berdampak kemandegan setelah disahkan. Kemudian dibahas dan disahkan kembali setelah dilakukan revisi ulang dengan dihapuskannya ketentuan hukum rajam. Metode yang digunakan adalah penelitian kualitatiffenomenologis, dengan pendekatan sejarah (historical approach). Hasil kajian menunjukkan bahwa memuat hukum rajam bagi pezina muṣsan dalam Qanun Hukum Jināyah tidaklah bertentangan dengan nas hadis, dan ini telah disepakati oleh para ulama. Ketentuan hukum rajam juga tidak melanggar Hak Asasi Manusia, melainkan termasuk tujuan syara' (maqạsid al-shari'ah) dalam penetapan hukum, yaitu demi kemaslahatan manusia, dalam rangka melindungi keturunan (bif a al-nas) sebagai pemenuhan kebutuhan daruriyyah (primer) dari mafsadat.

Keywords: Legislation; Law of positive Aceb; Wrestling; Qanun Law Jinäat 
Ijtihad, Jurnal Wacana Hukum Islam dan Kemanusiaan, Volume 14, No. 2, Desember 2014: 149-166

\section{Pendahuluan}

Diskursus tentang pengesahan Qanun Hukum jināäat di Provinsi Aceh masih menjadi polemik di kalangan masyarakat. Diskursus ini terjadi antara dua kubu yang saling berlawanan, yaitu kubu ulama dan kubu sipil, yaitu jaringan yang terdiri dari Koalisi lembaga-lembaga non pemerintah seperti Hak Asasi Manusia (HAM) Aceh, Komite untuk Tindak Kekerasan (Kontras) Aceh, Lembaga Bantuan Hukum (LBH) Aceh, Lembaga Bantuan Hukum (LBH) APIK Aceh, Flower Aceh, Tikar Pandan, Radio Suara Perempuan, Violet Grey, Sikma, Pusat Studi Hak Asasi Manusia Universitas Syiah Kuala, dan Yayasan Sri Ratu Safiatuddin.

Kubu ulama sebagai pendukung aktif menghendaki Qanun Hukum Jinäyät segera mungkin dapat disahkan agar payung hukum yang lebih kuat dalam pelaksanaan dan penegakan Syariat Islam yang telah menjadi kesepakatan mayoritas masyarakat Aceh (The Wahid Institute, 2009: 1). Sedangkan kubu sipil sebagai kelompok yang kontra (menolak) menginginkan Qanun tersebut tidak disahkan. Mereka mencatat telah terjadi peminggiran terhadap aspirasi masyarakat sipil, yang tergabung dalam Tim Perumus draft Rancangan Qanun tersebut (The Wahid Institute, 2009: 1).

Benih-benih perseteruan ini sudah muncul sejak draft rancangan Qanun Hukum Jināäăt dirumuskan oleh Eksekutif, kemudian diserahkan dan dilanjutkan pembahasannya oleh Legislatif. Polemik pro-kontra secara terbuka terjadi pada pemahaman substansial pasal 'uqū bàt tentang hukum rajam. Menurut ulama, penerapan hukum rajam merupakan bagian dari kebebasan menjalankan agama, termasuk penerjemahan konteks "kekhususan" Aceh melalui UU No. 11 Tahun 2006 tentang Pemerintahan Aceh. Begitupun sebelumnya, Qanun No. 13 Tahun 2003 tentang Perjudian telah berjalan dan salah satunya berisi hukum cambuk. Sementara kelompok sipil menganggap hukum rajam bertentangan dengan HAM, diskriminasi, melanggar prinsip-prinsip pembuatan peraturan perundang-undangan (Ula, 2004: 68-69).

Dampak dari pergumulan itu, Qanun Hukum Jināyat yang disahkan oleh badan legislatif (DPR) Aceh, tidak ditandatangani oleh Gubernur sebagai kepala daerah yang mempunyai hak otoritas pengakuan suatu peraturan (Qanun). Terkait dengan ini terjadi kevakuman dari tahun 2009 sampai pertengahan 2014, dan pada akhir bulan September Qanun ini disahkan dengan dihapuskan hukum rajam. Hal ini didukung oleh Gubernur Hasbi Abdullah yang 
telah memberi signal positif, didukung moyoritas partai Aceh (The Wahid Institute, 2009: 2). Apabila hal ini benar terjadi, maka Aceh telah mengukir sejarah dalam menciptakan hukum positif (fikih) Aceh di bidang jinājāt (pidana Islam) secara menyeluruh.

Menanggapi fenomena di Aceh tersebut dapat dipaparkan dua pemikiran tokoh besar sebagai pertimbangan menyahuti pergumulan yang muncul di atas. (Al-Jabiri, 2001: 127) mengatakan bahwa sebagian fenomena kebangkitan Islam menuntut penerapan sistem Islam dalam semua aspek kehidupan. Namun perlu disadari bahwa tidak ada sistem Islam yang siap pakai, terperinci dan mencakup keseluruhan aspek kehidupan (Al-Naim, t.th: 39). menegaskan bahwa Syariat tidak dapat diundangkan sebagai hukum positif karena memang bertentangan dengan asas kesukarelaan umat Islam, dan akan tetap menjadi sumber dari sistem sangsi agama yang bersifat normatif.

Permasalahan ini pada tataran ilmiah sangat layak dan aktual untuk dikaji secara komperehensif, sehingga menemukan suatu pemikiran kontruktif yang dapat memberikan kontribusi untuk masa depan Aceh yang demokratif terhadap pergumulan Qanun Hukum Jinäyät sebagai hukum positif (fikih) Aceh.

\section{Filosofi dan paradigma legislasi Qanun Hukum Jināyāt}

Dalam perjalanan panjang sejarahnya, masyarakat Aceh dikenal sebagai masyarakat yang sangat dekat bahkan fanatik terhadap ajaran Islam, sehingga Islam menjadi identitas budaya dan kesadaran jati diri. Masyarakat Aceh menyatukan ajaran agama ke dalam adat istiadat dan hukum adat sedemikian rupa, sehingga menyatu dan terbaur, yang dalam pepatah adat dinyatakan dengan ungkapan: Hukom ngoen adat lage dzat ngoen sifeut (hubungan syariat dengan adat adalah ibarat hubungan suatu zat [benda] dengan sifatnya), yaitu melekat dan tidak dapat dipisahkan (Sulaiman, 1992: 82).

Pada masa sekarang, pelaksanaan syariat Islam di Aceh adalah amanat dan perintah paling kurang dari tiga UU, yaitu; UU No. 44 Tahun 1999 tentang Penyelenggaraan Keistimewaan Aceh bagi Provinsi Nanggroe Aceh Darussalam; UU No. 11 Tahun 2006 tentang Pemerintahan Aceh; dan UU No. 48 Tahun 2007 tentang Penetapan Peraturan Pemerintah Pengganti UU No. 2 Tahun 2007 tentang Penanganan Permasalahan Hukum dalam Rangka Pelaksanaan Rehabilitasi dan Rekonstruksi Wilayah dan Kehidupan Masyarakat 
ljtihad, Jurnal Wacana Hukum Islam dan Kemanusiaan, Volume 14, No. 2, Desember 2014: 149-166

di Provinsi Nanggroe Aceh Darussalam dan Kepulauan Nias Provinsi Sumatera Utara.

Lebih khusus lagi adalah lahirnya UU No. 18 Tahun 2001 tentang Otonomi Khusus bagi Propinsi Daerah Istimewa Aceh sebagai Provinsi Nanggroe Aceh Darussalam. UU ini memperkenalkan Qanun sebagai wadah untuk syariat Islam yang akan dijalankan sebagai hukum positif di Aceh, sebagai bagian dari sistem hukum nasional. UU ini juga memperkenalkan peradilan syariat Islam di Aceh yang akan dilakukan oleh Mahkamah Syar'iyyah (Ka'bah, 2004: 26) sebagai bagian dari sistem peradilan nasional dan dibantu oleh Kepolisian dan Kejaksaan. Kemudian UU No. 18 Tahun 2001 ini dicabut dan dinyatakan tidak berlaku oleh UU No. 11 tahun 2006.

Berdasarkan UU No. 18 Tahun 2001, Pemerintah Provinsi membentuk panitia untuk menghimpun bahan, menetapkan bidang dan langkah kerja serta menulis rancangan qanun aceh sebagai hukum positif di Aceh tentang pelaksanaan Syariat Islam dalam berbagai aspek kehidupan. Untuk itu, Panitia menetapkan tiga bidang penulisan Rancangan Qanun dengan langkah-langkahnya sebagai berikut: Pertama, bidang pertama penulisan Qanun Aceh tentang peradilan Syariat Islam (al-qāa) itu sendiri serta Qanun di bidang aqidah, ibadat (shalat, puasa, zakat dan rumah ibadat/masjid) serta syiar Islam; Kedua, bidang kedua penulisan Qanun di bidang jinääat (pidana) materiil dan formil dan; Ketiga, bidang ketiga penulisan Qanun di bidang mu'amalat (perdata keharta-bendaan) materiil dan formil.

Untuk bidang yang kedua, yaitu penulisan Qanun di bidang jināyāt, Panitia mengelompokkan persoalan menjadi empat kelompok besar yang sekaligus menjadi langkah penulisannya yaitu: penulisan peraturan (Qanun dan Peraturan Gubernur) yang berkaitan dengan perlindungan akhlak, kesusilaan dan kehormatan diri, (keluhuran akhlak dan moral); penulisan peraturan yang berkaitan dengan perlindungan nyawa manusia; penulisan peraturan yang berkaitan dengan perlindungan harta kekayaan; dan Adapun penulisan peraturan yang berkaitan dengan hukum acara, akan dilakukan secara bertahap sesuai dengan hukum materil yang memerlukannya.

Untuk langkah pertama disahkan tiga buah Qanun (Himpunan, 2004): Pertama, Qanun Provinsi Nanggroe Aceh Darussalam Nomor 12 Tahun 2003 tentang Minuman Khamar dan Sejenisnya; Kedua, Qanun Provinsi Nanggroe Aceh Darussalam Nomor 13 Tahun 2003 tentang Maisir (Perjudian); dan ketiga, Qanun Provinsi Nanggroe Aceh Darussalam Nomor 
14 Tahun 2004 tentang Khalwat (Mesum).

Pemilihan tiga masalah di atas untuk dituliskan ke dalam Qanun sebagai Qanun awal di bidang pidana, dilakukan paling kurang karena dua pertimbangan. Pertama, perbuatanperbuatan tersebut merupakan maksiat (haram) dalam syariat dan relatif sangat meresahkan masyarakat Aceh namun belum tertangani secara baik. Perbuatan meminum khamar dan melakukan khalwat tidak merupakan perbuatan pidana dalam hukum nasional; sedang maisir hanya yang tidak mendapat izin yang merupakan perbuatan pidana. Kedua, terjadi euforia di berbagai lapisan masyarakat di Aceh, dalam bentuk "pengadilan rakyat" yang muncul di tengah masyarakat terhadap ketiga jenis perbuatan pidana di atas, segera setelah UU No. 44 Tahun 1999 disahkan. Antara bulan September sampai Desember 1999 tercatat belasan kasus dalam tiga masalah di atas, yang diselesaikan masyarakat melalui "pengadilan rakyat" di berbagai tempat di Aceh.

Seperti diketahui 'uqū bāt cambuk pertama dijatuhkan pada bulan Januari 2005 dan eksekusinya dijalankan pada Juni 2005. Pada saat itu telah terlihat berbagai kelemahan pada Qanun yang ada, baik di bidang materiil ataupun formilnya. Memang sejak awal ditulis dan disahkan sudah direncanakan bahwa Qanun-Qanun ini akan direvisi dan disempurnakan setelah dilaksanakan secara nyata di lapangan. Dalam arti telah ada tersangkanya, ada proses penyidikan, penuntutan, penyidangan dan pembacaan putusan sampai tingkat berkekuatan hukum tetap termasuk kasasi, dan setelah itu ada pelaksanaan 'uqübät oleh jaksa penuntut umum. Menurut rencana, setelah disahkan pada tahun 2003 yang lantas diikuti dengan sosialisasi, maka Qanun ini akan dilaksanakan tahun 2004. Setelah itu dilakukan revisi tahun 2005. Karena berbagai sebab, diantaranya musibah tsunami dan MoU Helsinki yang kemudian disusul dengan kehadiran UU No. 11 Tahun 2006, maka revisi dan penyempurnaan atas tiga Qanun di atas baru dapat terlaksana dan dibicarakan di DPRA pada tahun 2009. Tetapi karena ada perbedaan pendapat antara Eksekutif dan Legislatif, maka rancangan tersebut tidak jadi disahkan, walaupun sudah disetujui oleh fraksi-fraksi yang ada di DPRA dalam Sidang Paripurna mereka. Sesudah itu baru pada tahun 2014 ini revisi dan penyempurnaan tersebut dapat disahkan. 
Ijtihad, Jurnal Wacana Hukum Islam dan Kemanusiaan, Volume 14, No. 2, Desember 2014: 149-166

\section{Paradigma legislasi Qanun Hukum Jināyāt}

Prinsip utama yang menjadi pegangan serta metode penulisan rancangan Qanun tentang pelaksanaan Syari'at Islam dari perspektif usul fikih, ada empat pokok pikiran (prinsip) yang menjadi pegangan utama yang perlu dikemukakan dalam penjelasan ini (Yahya, 2012: 135), sebagai berikut:

Pertama, ketentuan-ketentuan yang akan dilaksanakan itu harus tetap bersumber kepada al-Qur'an dan Sunnah Rasulullah; Kedua, penafsiran atau pemahaman atas al-Qur'an dan Hadis tersebut akan dihubungkan dengan keadaan dan kebutuhan lokal (adat) masyarakat Aceh pada khususnya atau dunia Melayu Indonesia pada umumnya, serta dengan tata aturan yang berlaku dalam kerangka NKRI; Ketiga, penafsiran dan pemahaman tersebut akan diupayakan untuk selalu berorientasi ke masa depan, guna memenuhi kebutuhan masyarakat Indonesia yang sedang membangun di awal abad XV H atau abad XXI M, serta mampu menyahuti "semangat" zaman modern seperti tercermin dalam isu perlindungan HAM dan kesetaraan gender, serta mempertimbangkan kemajuan ilmu dan teknologi terutama sekali ilmu hukum, yang perkembangannya relatif sangat cepat dan pesat, dan Keempat, guna melengkapi tiga prinsip di atas dipedomani prinsip yang terkandung dalam sebuah kaidah fikih kulliah yang dikenal luas (Djazuli, 2006: 193): almuḥafazah 'ala al-qad̄im al-șalih wa al-akhdhu bi al-jadid al-așlạ̣ (memelihara keadaan yang lama yang maslahat dan mengambil yang baru yang lebih maslahat.

Kaidah ini dimaksudkan sebagai penetapan yang dituangkan ke dalam Qanun Hukum Jinääat, namun tetap memakai ketentuan-ketentuan lama (madhhab) yang masih baik (relevan) dan berusaha mencari serta merumuskan ketentuan baru yang lebih baik dan lebih unggul". Sementara pilihan untuk menggunakan empat prinsip penafsiran di atas menjadi penting sekiranya diingat bahwa upaya pelaksanaan Syariat Islam di Aceh dalam kerangka NKRI sekarang, adalah sebuah "terobosan besar dan penting” yang diberikan oleh negara kepada masyarakat Aceh untuk mencari dan merumuskan sebuah "model" penerapan hukum berdasar Syariat Islam di dalam masyarakat dan negara modern (Ridwan, 2008: 76) .

Berdasarkan keempat prinsip di atas diharapkan Syariat Islam yang dituangkan ke dalam Qanun Aceh yang menjadi sub-sistem dalam sistem hukum nasional dan sistem peradilan nasional ini, akan tetap berada di bawah naungan al-Qur'an dan Sunnah Rasulullah dan tetap berada dalam bingkai sejarah panjang pemikiran fikih dan penerapan syariat Islam di berbagai belahan dunia. Begitu juga Qanun-qanun ini akan tetap bertumpu pada budaya dan adat 
istiadat lokal masyarakat Indonesia, khususnya masyarakat Aceh, serta sistem hukum yang berlaku di dalam NKRI. Dengan demikian kegiatan dan pilihan ini diharapkan mampu mewujudkan sebuah tatanan hukum (fikih) baru yang berakar dan menyatu dengan kesadaran hukum rakyat serta mampu memenuhi kebutuhan masa depan bangsa yang semakin rumit dan kompleks, serta tidak tersandung pada tuduhan mengabaikan perlindungan HAM dan kesetaraan gender. Dalam ungkapan masyarakat lokal yang dikutip dari al-Qur'an, upaya ini sering dinyatakan sebagai upaya untuk merumuskan aturan hukum yang "rahmatan lil "álamin".

Beralih kepada cara yang ditempuh untuk menentukan perbuatan pidana, bagaimana cara, apa ciri, dan atau apa rukun dan syarat yang diperlukan agar sebuah perbuatan dapat ditetapkan sebagai jarimah (perbuatan pidana), maka Qanun ini cenderung mengikuti ketentuan yang ada dalam fikih itu sendiri. Dalam fikih ada dua cara untuk menetapakan bahwa suatu perbuatan adalah järmah. Cara yang pertama, al-Qur'an atau hadis sendiri yang menyatakannya sebagai perbuatan yang harus dijatuhi hukuman ('uqū $\bar{a} \bar{a}$ ), misalnya al-Qur'an menyatakan bahwa penzina dicambuk seratus kali, pembunuh dikenai qicâc atau diyat. Perbuatan jenis ini diidentifikasi sebagai jarimah ḥudud, yaitu tindak pidana yang diancam dengan hukuman ḥadd, yaitu hukuman yang telah ditetapkan kadarnya oleh al-Qur'an dan al-Hadis, tidak ada dua batas (batas terendah dan batas tertinggi) dan tidak dapat diganti dengan hukuman lain, karena merupakan hak Allah (Atiyyah dan Al-Zuhaili, 2000: 328; Sabiq, 1983: 302). Tetapi Al-Maliki (2002: 19-20) tindak kejahatan yang menjadikan pelakunya dikenakan sanksi ḥadd, yaitu sanksi yang telah ditetapkan kadarnya oleh syara' bagi suatu tindak kemaksiatan, untuk mencegah pelanggaran pada kemaksiatan yang sama.

Di dalam hadis disebutkan bahwa Rasulullah menyuruh Sahabat memukul (mencambuk) orang yang terbukti meminum khamar. Akan tetapi sebagian ulama menyatakan jarimah dan 'uqụbat minum khamar sebagai ḅudūd, sementara sebagian lagi menyatakannya sebagai ta'żir, yaitu hukuman yang tidak ditentukan oleh nas yang berkaitan dengan kejahatan yang melanggar hak Allah dan hak hamba yang berfungsi untuk memberikan pelajaran kepada pelaku kejahatan dan mencegahnya untuk tidak mengulangi kejahatan serupa (Musyarrafah, 1966: 149; AlAmir, 1976: 52; dan Al-Zarqa, 1968: 626).

Model yang kedua, ditetapkan dengan salah satu dari tiga cara; Pertama, ayat al-Qur'an atau Hadis menyatakan/menetapkan perbuatan tersebut berbahaya untuk masyarakat. Kedua, 
manusia berdasarkan pertimbangan akal sehat berkesimpulan bahwa untuk ketertiban umum, perbuatan itu perlu diatur dan pelanggarannya dapat dijatuhi 'uqū $\bar{a} \bar{t}$, seperti peratutan untuk tertib lalulintas. Cara yang ketiga, perbuatan tersebut merupakan perbuatan pendahuluan yang sekiranya diteruskan akan menjadi jarimah kelompok yang pertama ( $(\underline{u} \bar{u} \bar{u} d)$, misalnya khalwat dan ikhtilat, atau merupakan perbuatan yang sudah masuk ke dalam lingkup atau menjadi bagian dari jarimah kelompok yang pertama, misalnya menjual khamar, menyediakan tempat untuk melakukan maisir atau membantu atau membujuk orang akgar melakukan zina atau pemerkosaan dan seterusnya. Perbuatan jenis ini oleh ulama fikih disepakati sebagai jarimah ta'

Penetapan jenis dan bentuk 'uqū bät, serta berat atau ringan 'uqū $\bar{b} \bar{t}$ yang akan dijatuhkan tersebut, diserahkan kepada masyarakat muslim itu sendiri untuk menentukan atau merumuskannya. Untuk kasus Aceh, kewenangan penyusunan secara formal oleh undangundang diserahkan kepada Pemerintah Aceh dan DPRA, sedang secara substansial penulisan rancangannya dipersiapkan para ulama dan para sarjana. Begitu juga pembahasannya di DPRA didampingi oleh para ulama, para sarjana dan para praktisi.

Mengenai kerugian yang ditimbulkan, berhubung jarimah dalam Qanun ini pada pokoknya berupaya memberi perlindungan pada akhlak, maka kerugian utama yang ditimbulkannya pun berhubungan dengan akhlak, lebih banyak menimpa diri sendiri dari orang lain. Meminum khamar akan merugikan orang yang meminumnya, begitu juga maisir akan merugikan orang yang melakukannya. Dengan demikian kerugian "langsung” yang ditimbulkan oleh jarimah (yang dirumuskan di dalam Qanun ini), hanya sedikit yang berhubungan dengan orang lain, misalnya pemerkosaan, pelecehan seksual, menjual khamar, dan seterusnya. Kerugian yang menimpa orang lain harus disebutkan kerugian "langsung", karena kerugian tidak langsung atau kerugian jangka panjang dari pelanggaran jarimah-jarimah tersebut seperti keruntuhan akhlak, kemiskinan, hilangnya kesetiakwananan, dan sebagainya, kuat dugaan akan terjadi dalam jangka panjang.

Mengenai jenis 'uqūbāt, dalam al-Qur'an sudah disebutkan beberapa jenis seperti: 'uqūbāt mati (qișass), 'uqūbāt amputasi (potong tangan), uqubat penjara (kurungan dalam rumah, diasingkan), 'uqübāt cambuk dan 'uqübät diyat (semacam ganti rugi yang dibayarkan pelaku kepada korban penganiayaan atau keluarga korban pembunuhan) dan 'uqūbat denda. Perincian 
dan penjelasan lebih lanjut tentang rumusan, bentuk, serta tata cara penjatuhannya oleh hakim dan pelaksanaannya oleh Jaksa Penuntut Umum relatif masih sangat terbuka untuk dikembangkan dan dalam kenyataan telah diijtihadkan oleh para ulama dari berbagai mazhab. Walaupun harus disebutkan bahwa pengembangan (ijtiba $\bar{d}$ ) pada ḥudud relatif lebih terbatas dibandingkan dengan pengembangannya pada järimah ta'żir.

Pada järimah ta'šir ada kemungkinan untuk memperluas atau menambah 'uqū bāt dengan jenis 'uqū bät lain yang dianggap layak dan sejalan dengan prinsip Syari'ah. Di dalam Qanun

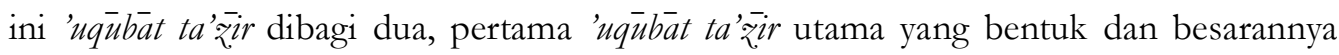
ditentukan dalam Qanun, dan yang kedua 'uqū $\bar{u}$ at ta' 2 ir pelengkap yang hanya bentuknya ditentukan dalam Qanun. Sedang besarannya dan alasan serta pertimbangan untuk menjatuhkannya akan diatur dalam Peraturan Gubernur sehingga akan lebih lentur. Qanun memberi izin kepada hakim untuk menjatuhkannya walaupun tidak dituntut oleh jaksa penuntut umum. Dengan demikian hakim juga bisa tidak menjatuhkannya walaupun dituntut oleh jaksa penuntut umum.

Mengenai kesetaraan 'uqūbāt, dalam Qanun Provinsi Nomor 11 Tahun 2002 ditetapkan bahwa satu kali cambuk sama dengan dua bulan penjara, sama dengan denda Rp. 500.000,Alasan dan pertimbangan yang dipakai pada waktu itu adalah menyamakan seratus kali cambuk sebagai uqubat cambuk tertinggi yang ada dalam nac (al-Qur'an) dengan penjara dua ratus bulan (16 tahun delapan bulan) sebagai hukuman penjara tertinggi dalam KUHP, dan denda Rp 100.000.000,- (taksiran harga untuk 100 ekor anak lembu, 'uqüuät diyat untuk pembunuhan tidak sengaja).

Di dalam Qanun jinäyät ini, berdasarkan bahan bacaan dan masukan dari banyak pihak, dan kenyataan di lapangan, diupayakan melakukan perbaikan sebagai berikut. Hukuman mati atau diyat yaitu membayar 100 (seratus) ekor unta dewasa (sebagai 'uqū $\bar{a} \bar{t}$ untuk pembunuhan sengaja) dianggap sebagai 'uqübat tertinggi, tepatnya 'uqūūät denda tertinggi. 'Uqübät ini disamakan dengan hukuman penjara seumur hidup atau penjara tertinggi yang ada dalam KUHP yaitu 15 (lima belas) tahun (untuk memudahkan dibulatkan menjadi 200 (dua ratus) bulan). Adapun hukuman lain yang ditentukan oleh nac, yaitu cambuk seratus kali (untuk perbuatan zina) dan potong satu tangan (untuk pencurian) harus dianggap sebagai hukuman yang lebih rendah dari itu. 'Uqū băt cambuk 100 (seratus) kali dianggap sama 
Ijtihad, Jurnal Wacana Hukum Islam dan Kemanusiaan, Volume 14, No. 2, Desember 2014: 149-166

dengan separuh hukuman mati, dengan alasan hukuman tertinggi dalam masalah perlindungan kehormatan dan kejahatan seksual ini adalah hukuman untuk para pemerkosa yang beratnya direncanakan dua kali hukuman untuk orang-orang yang berzina. Dengan demikian hukuman cambuk seratus kali dianggap sama dengan penjara 100 (seratus) bulan dan harga 50 ekor unta.

Sedang mengenai 'uqū $\bar{a}$ t denda dan restitusi, di dalam buku-buku fikih ditemui hadis yang menyatakan bahwa pada masa Nabi diyat berat, yaitu 100 (seratus) ekor unta dewasa dianggap sama dengan harga 1000 (seribu) dinar emas, lebih kurang sama dengan 4200 (empat ribu dua ratus) gram emas pada masa sekarang. Berdasarkan pendapat ini uqubat mati dapat disamakan dengan denda sebesar 4000 (empat ribu) gram emas (dibulatkan). Dengan demikian, setengah hukuman mati, yaitu hukuman cambuk seratus kali dapat disamakan dengan denda 2000 (dua ribu) gram emas. Berdasarkan uraian di atas maka satu kali hukuman cambuk pada dasarnya dianggap sama dengan penjara satu bulan atau denda sebesar 20 (dua puluh) gram emas. Namun demikian, dengan mempertimbangkan kondisi ekonomi masyarakat di Aceh, penetapan denda dengan menggunakan emas dalam jumlah yang relatif besar terasa sangat memberatkan. Oleh karena itu, besaran 'uqū bāt denda diturunkan jumlahnya hingga 50\% dari ketentuan asal. Dengan demikian, ditetapkan kesetaraan baru 1 (satu) kali cambuk setara dengan 1 (satu) bulan penjara, dan setara pula dengan denda 10 (sepuluh) gram emas.

Emas dipilih untuk menentukan besaran 'uqū bät denda, di samping karena lebih sesuai dengan hadis Rasulullah, juga karena dianggap lebih stabil, sehingga tidak akan terjadi kesenjangan antara 'uqū $\bar{a}$ t denda dengan 'uqū bät lainnya karena adanya inflasi setelah waktu berjalan beberapa lama. Untuk memudahkan, Ketua Mahkamah Syar'iyyah Aceh diberi kewenangan untuk menetapkan kesetaraan harga emas dengan uang rupiah secara berkala. Mahkamah Syar'iyyah Penetapan ini akan diubah dan disesuaikan setiap ada perbedaan dengan harga pasar. Ketua Mahkamah Syar'iyyah wajib melakukan penyesuaian apabila harga dalam penetapan telah berbeda lebih dari sepuluh persen dengan harga di pasaran, baik lebih mahal ataupun lebih murah.

Untuk jarimah ḥudud, Qanun ini tidak menganut prinsip 'uqūbāt alternatif. Sedangkan untuk jarimah ta' '̄ir menganut prinsip 'uqū bät alternatif yaitu cambuk atau denda atau penjara. 
Berdasarkan alur pikir di atas, maka 'uqūbat ḅudùd zina ditetapkan 100 (seratus) kali cambuk dan uqubat minum khamar ditetapkan 40 kali cambuk. Namun untuk orang yang sudah diputus bersalah, yang mengulangi kembali jarimah yang sama (residivis), maka hakim dapat menambah dengan 'uqüüät ta'žir yang ditentukan di dalam qanun ini. Sedangkan untuk 'uqū bät ta'zir seperti khalwat ditetapkan 10 (sepuluh) kali cambuk setara dengan 10 (sepuluh) bulan penjara atau 100 (seratus) gram emas murni. Sedang 'uqübät ta'żir yang dianggap lebih berbahaya dari jarimah ḥudūd, yaitu pemerkosaan ditetapkan 'uqū $\bar{u} a \bar{t}$ yang lebih berat, namun tetap bersifat alternatif, ntara cambuk, denda dan penjara.

Prinsip bahwa 'uqū bäat ditetapkan secara alternatif dimaksudkan untuk memberi keleluasaan kepada bagi hakim untuk berijtihad guna lebih mendekatkan dan memenuhi rasa keadilan masyarakat. Dalam beberapa kasus, misalnya pengulangan dan pemerkosaan hakim berdasarkan pertimbangannya dapat menetapkan 'uqū bàt tambahan, sehingga 'uqū $\bar{a} \bar{t}$ yang dijatuhkan secara kumulatif telah melebihi ketentuan 'uqū $\bar{a} \bar{t}$ untuk ḅudud. Adapun besaran 'uqūbāt, dalam Qanun ini ditetapkan batasan tertinggi dan terendah. Untuk batasan terendah ada tiga bentuk. Bentuk yang pertama ditentukan langsung pada masing-masing jarimah. Sedangkan yang kedua adalah batasan umum, yaitu seperempat dari batasan tertinggi. Adapun bentuk yang ketiga tidak disebutkan, yaitu 'uqū $\bar{u}$ at Utama yang dijadikan sebagai tambahan. Jadi unutk yang ketiga ini batas terendahnya adalah 'uqū bät terendah yang dapat disetarakan yaitu cambuk satu kali, penjara satu bulan atau denda 20 gram emas murni.

Selain 'uqū bāt Utama, Hakim atas pertimbangannya dapat juga menjatuhkan 'uqū $\bar{a} \bar{t}$ Pelengkap walaupun tidak diminta (dituntut) oleh jaksa penuntut umum. Dengan demikian hakim diberi kekuasaan yang relatif besar untuk menjatuhkan 'uqübät, dan inilah yang memang digariskan dalam hukum (fikih) Islam bahwa hakim bukanlah semata-mata sebagai 'corong' undang-undang. Peluang untuk menjatuhan 'uqū bät pelengkap dibuka di dalam qanun ini agar rasa keadilan yang tumbuh dan berkembang di dalam masyarakat, yang mungkin berbeda antara satu kasus dengan kasus lain, atau satu daerah dengan daerah lainnya, atau satu waktu dengan waktu lainnya, dapat tertampung. Sedangkan berkaitan dengan ketentuan umum, pada dasarnya megikuti ketentuan umum dalam Kitab Undang-Undang Hukum Pidana (KUHP), kecuali yang disebutkan lain di dalam Qanun ini, atau tidak sejalan dengan prinsipprinsip syariat Islam. 
Ijtihad, Jurnal Wacana Hukum Islam dan Kemanusiaan, Volume 14, No. 2, Desember 2014: 149-166

\section{Qanun Hukum Jināyāt sebagai hukum positif (fikib) Aceh}

Berdasarkan pemaparan paradigma legislasi Qanun Hukum jinäyät di atas, maka Qanun Aceh dalam bidang pidana Islam dapat menjadi sebagai hukum positif (fikih) Aceh yang menjadi sub-sistem nilai dan atau payung hukum di bawah naungan nas dan dalam bingkai sejarah pemikiran fikih di berbagai belahan dunia. Hal ini menunjukkan integritas Qanun itu sebagai hukum positif (fikih) di Aceh yang akan menjadi living law dalam masyarakat. Dari itu, ia menjadi nilai dominan dalam kehidupan sehari-hari, baik dalam bentuk kandungan spiritual, bahasa, budaya, maupun praktik perilaku.

Apa yang menjadi sandaran pemikiran yang hendak dibangun terkait dengan pengesahan Qanun Hukum Jinäyät di Aceh, maka acuan yang mendasar memerlukan konsep taghÿir sebagai perubahan bersifat total yang diawali dari asas (ide dasar) aqidah yang dapat melahirkan berbagai ide cabang, baik individu seorang muslim maupun masyarakat Islam, yang menjadi asas adalah Aq̄idah Islamiyyah, (Attamimi, 1996: 151). Perubahan total ini tertuju pada kerusakan sesuatu yang bersifat mendasar dan fatal, sehingga harus diadakan perubahan pada asasnya yang berlanjut pada cabang-cabangnya. Adapun iclah adalah perubahan yang bersifat parsial, dengan asumsi bahwa asas yang ada masih selamat/benar, atau hanya terkotori oleh sesuatu ide asing.

Transformasi hukum Islam dalam bentuk Qanun (takhrij al-aḅkam fi al-nas al-qāaūn) Hukum Jinäyat merupakan produk interaksi antar elite politik Islam (para ulama, tokoh ormas, pejabat agama dan cendekiawan muslim) dengan elite kekuasaan (the ruling elite) yakni kalangan politisi dan pejabat daerah. Adapun prosedur pengambilan keputusan politik di tingkat legislatif dan eksekutif terhadap legislasi hukum Islam (legal drafting), (Al-Asyqar, 1982: 187188 dan Mutawalli, 1985: 22), hendaknya mengacu kepada politik hukum yang dianut oleh badan kekuasaan pemerintah daerah secara kolektif. Suatu Qanun dapat ditetapkan sebagai peraturan tertulis yang dikodifikasikan apabila telah melalui proses politik pada badan kekuasaan daerah, yaitu legislatif dan eksekutif, serta telah memenuhi persyaratan dan rancangan Qanun Hukum Jināät yang layak.

Qanun Hukum Jinäyät di Aceh dalam konteks siyasah al-shar'iyyah adalah suatu keharusan supaya perbuatan-perbuatan mukallaf yang dilarang agama dapat dikendalikan sesuai pentadbir-an jiwa syari'ah. Hukum positif Aceh (atau bisa disebut fikih Aceh, atau fikih mazhab 
negara/Aceh) akan representatif jika pembentuk Qanun mampu meminimalisir pengaruh politik sektarian dan emosional serta fanatisme mazhab. Karena itu, tingkat kalaborasi ulama sebagai mujtabid al-Qānūn (penyusun Qanun) dan lembaga legislatif (DPRA Aceh) sebagai wad'i al-Qā̄ūn (pembentuk Qanun) mutlak diperlukan bersama.

Pembentukan Qanun Hukum Jināyāt adalah sebagai upaya pencegahan tindak pidana yang berdimensi hukum Islam dan selanjutnya konsep-konsep Qanun tersebut dapat mengakomodir untuk dijadikan hukum positif (fiqih) Aceh. Dengan demikian akan melahirkan suatu aturan hukum Jināyāt di Provinsi Aceh yang berdimensi hukum Islam dalam rangka menciptakan kemaslahatan sesuai maqāșìi al-sharīah, yaitu hịł ạ al-dīn sebagai bentuk menjaga dan memelihara daerah yang nyaman, seralas dan berkemakmuran yang dapat dirasakan oleh rakyat Aceh.

\section{Pergumulan legislasi Qanun Hukum Jināyāt di Aceh}

Beberapa persoalan penting yang menjadi pergumulan antara kelompok ulama dan kelompok sipil dalam Qanun Hukum Jināäat yang telah pernah disahkan tahun 2009 oleh lembaga legislatif (selanjutnya tidak ditandatangani oleh Gubernur) adalah pada pencantuman 'uqūüát rajam bagi pezina mubșan (telah/pernah menikah) dan berkaitan dengan Hak Asasi Manusia (HAM). Sementara dalam revisi selanjutnya rancangan Qanun Aceh tentang Hukum Jinājät dan sekarang telah disahkan kembali, materi hukum rajam telah dihapuskan sebagai 'uqū băt ḅudud.

Kedua permasalahan yang diperdebatkan oleh kelompok sipil tersebut akan dikaji dengan argumentatif yang dapat dijadikan landasan dalam menyahuti persoalan pergumulan yang berkembang. Adapun penjelasannya sebagai berikut:

\section{Hukum rajam}

Dalam al-Qur'an hukuman bagi pelaku tindak pidana zina diturunkan tiga tahap (Al-Asmawi, 2005: 129), yaitu; Pertama, dikurung di rumah seumur hidup atau diberikan jalan lain oleh Allah Swt.; Kedua, hukuman yang tak terbatas itu diserahkan bentuk dan ukurannya pada pemerintah (waliyy al-amr) tergantung pada situasi dan kondisinya; dan ketiga, hukuman jilid (cambuk), bukan rajam (lempar batu hingga mati).

Hukuman yang pertama dan ketiga di atas disebutkan dalam hukum Islam (Ali, 2006: 111), sedangkan hukuman yang ketiga tidak dinyatakan kecuali al-Asmawi tadi. Sementara 
Ijtihad, Jurnal Wacana Hukum Islam dan Kemanusiaan, Volume 14, No. 2, Desember 2014: 149-166

(Ridwan, 2008: 24) menyebutkan zina ditetapkan QS. al-Nisā‘: 15-16 dengan hukuman pezina perempuan ditahan di rumah keluarganya samapi ia mati atau Allah menurunkan hukum yang baru mengenai para pezina. Sedangkan pezina laki-laki adalah disakiti. Namun jika mereka bertaubat dan memperbaiki perilakunya maka dibiarkan tidak apa-apa.

QS. al-Nür: 2 diturunkan paling akhir dan hukuman ta' '̌ir yang semula di nasakh sehingga zina menjadi jarimah ḅudüd yang hukumnya ditetapkan dalam al-Qur'an (Al-'Awwa, 1983: 217). Meskipun ayat itu tidak menjelaskan hukuman rajam secara inplisit, tetapi para fuqaha menegaskan hukuman bagi pelaku zina yang belum menikah (ghairu muḥsan). Sementara bagi orang yang sudah menikah (muhsan) hukumannya menurut para ahli hukum Islam adalah rajam (dilempar batu) sampai mati, sebagaimana hadis Nabi Saw. riwayat Muslim dari 'Ubadah bin bâmit (Al-Naisaburi, t.th/II: 48). Hal ini diperkuat Syafi'i (Safwat, 1996: 67) bahwa hukuman zina bagi mụsan rajam. Ketentuan ini tidak diatur dalam Kitab UndangUndang Hukum Pidana (KUHP) atau ketentuan pidana di luar KUHP, kecuali ada pihak yang dirugikan akibat pelanggaran zina.

Dalam sejarah, pertama kali hukum rajam dilakukan Nabi Saw. adalah sesuai yang terdapat dalam kitab Taurat, yaitu dua orang yang berasal dari orang Yahudi Madinah. Penerapan hukuman rajam pada masa Nabi Saw. adalah karena adanya pengakuan berulang kali dari pelakunya, dan terjadi sebelum turunnya ayat cambuk. Ketika pelaku hukum rajam berusaha untuk melarikan diri karena kesakitan, tetapi pelaksana eksekusi tidak memberi kesempatan melainkan dieksekusi hingga mati. Mendengar berita ini Nabi Saw. marah dan bersabda: "mengapa kalian tidak meninggalkannya?" Itulah batas yang dikehendaki dalam Sunnah Nabi Saw. (Al-Asmawi, 2005: 134).

Dengan demikian, dosa-dosa pelaku zina dalam Islam adalah bersifat agama (diniyyah), yakni memperbaiki moral manusia bukan menghukumnya, sebab menghukum pelakunya bukanlah tujuan Islam. Oleh karena itu, tanggapan yang disampaikan oleh pihak-pihak tertentu adalah tidak ingin Qanun Hukum Jināal tegak di bumi Aceh dan cenderung kepada pemikiran sekuler dan budaya Barat yang sudah merasuk ke dalam pikiran sebagian umat Islam, (Al'Awwa, 1983: 217-222). 
Hak asasi manusia (HAM)

Munculnya 'uqū bāt rajam dalam Qanun Hukum Jināāat dipahami telah melanggar HAM dan sebagainya, sebenarnya itulah ajaran Islam yang harus dijaga, dipertahankan dan diamalkan -bukan mempertahankan hukum Barat dengan konsepnya "HAM". Karena konsep Barat itu tidaklah relevan dengan syari'at Islam (hukum Allah Swt.) yang berlandaskan akal pikiran. Islam mempunyai konsep Hak. Asasi (Zahrah, t.th: 291) dan kewajiban individu yang sangat mapan dan harus dipertahankan serta dijalankan oleh segenap umatnya tanpa memperadukkan dengan HAM konsep Barat. Tampaknya wawasan dan pemahaman tentang HAM ini dan apa itu kebebasan di seluruh dunia memang harus dirumuskan kembali (Ali Muhammad, 2004: xi).

Issue HAM sebagai suatu bentuk perlindungan, dalam syari'at Islam bukanlah sesuatu yang betul-betul baru. Karena istilah ḅuqūq al-ädami atau ḅuqūq al-'ibäd merupakan dua istilah klasik sebagaimana keklasikan fikih itu sendiri. Para ulama sepakat bahwa setiap individu manusia memiliki sepenuhnya apa yang menjadi haknya itu (Aboe El Fadl, 2004: 29). Dari itu para penguasa tidak boleh melakukan sesuatu yang melanggar atau mengurangi HAM, atau bahwa penguasa tidak mempunyai kekuasaan sedikitpun untuk mencabut hak-hak tersebut, seperti hak untuk mendapat ganti rugi akibat perbuatan yang tidak adil.

Dalam Islam, HAM sebenarnya telah terintegrasikan ke dalam salah satu sub disiplin ilmu seperti usul fikih. Melalui penalaran hukum (Al-Shatibi, t.th: 207), terdapat adanya pembahasan tentang perlindungan dan pemenuhan kebutuhan daruriyyah (kebutuhan primer), selain hạjiyyah (kebutuhan sekunder), taḥsiniyyah (tertier). Disinilah sebenarnya posisi HAM yang telah terintegrasikan. Oleh karena itu, kebutuhan daruriyyah sangat penting bagi setiap manusia dan harus dipertahankan, untuk memelihara atau mewujudkan lima hal pokok yang terangkum dalam al-Mabāid' al-Khamsah (Al-Ghâzali: 286), yaitu; perlindungan terhadap agama ( al-'aql), perlindungan terhadap keturunan (bifźal-nash), dan perlindungan terhadap harta (bif z. al-mäl).

Kelima perlindungan tersebut (Al-Syamibi, t.th/II: 7) merupakan wujud dari tujuan syara' (maquạsid al-shari'ah) dalam penetapan hukum, dimana di dalamnya mengandung maslahat dan dapat menafikan mafsadat (Al-Ghazali, t.th: 286). Nilai kemaslahatan itulah yang menjadi 
Ijtihad, Jurnal Wacana Hukum Islam dan Kemanusiaan, Volume 14, No. 2, Desember 2014: 149-166

hakikat dari pengakuan syara' terhadap hak asasi manusiawi baik menyangkut kepada individual (fardi) maupun kelompok (jamài). Oleh karena itu, Islam mempunyai konsep HAM yang adil, komperehensif dan mengigit dibandingkan konsep HAM yang sering disuarakan Barat sebagai perlindungan Hak-Hak Asasi Manusia. Oleh karena itu, hukum Islam menjadi mainstream dan hukum Barat menjadi komplementer.

\section{Penutup}

Legislasi Qanun Hukum Jināyāt di Aceh bukanlah sesuatu yang betul-betul baru, sebab jauh sebelumnya telah lahir berbagai taknin, seperti al-Fatawa al-Hindiyyah (India), al-Aḅkāam al'Adliyyah (Turki Usmani), Qanūn al-'Asyi (Aceh-tempo doeloe), dan sebagainya. Qanun Hukum Jinäät merupakan sebagai bentuk penegakan hukum terhadap järimah-jarimah dalam tata hukum pemerintahan Aceh yang mengikuti metode penulisan rancangan Qanun dari perspektif usulfikih dan berdasarkan materi fikih. Tanpa mengabaikan metodologi al-siyasah al-shar'iyyah dan metodologi taknin. Kedua metodologi ini saling terkait dalam rangka melahirkan sebuah peraturan (Qanun Hukum Jinääat). Dengan al-siyäasah al-sharïyyah, pemerintah mempunyai hak dan kewenangan untuk merumuskan dan menetapkan suatu peraturan bagi masyarakatnya, sehingga melahirkan takinin untuk dijalankan, dipatuhi dan ditaati secara bersama-sama.

Meskipun legislasi Qanun Hukum Jinääat telah memicu kontroversi luas di kalangan masyarakat Aceh. Tetapi setelah disahkan pada akhir bulan September lalu, kondisi Aceh kembali kondusif dari pergumulan itu. Sekarang keberadaan Qanun Hukum Jināyat ini ditunggu aksennya di kalangan masyarakat Aceh secara menyuruh pada setiap jenis kejahatan beserta 'uqübātnya, dengan mengedepankan prinsip tanpa pandang bulu atau strata kehidupan si pelaku.

\section{Daftar pustaka}

Ali Muhammad, Rusjdi. Hak. Asasi Manusia dalam Perspektif Syari'at Islam; Mengenal Jadi Diri, Hasan Basri (ed.). Jakarta: Mihrab, 2004.

Ali, Zainuddin. Hukum Islam: Pengantar Ilmu Hukum Islam di Indonesia. Jakarta: Sinar Grafika, 2006.

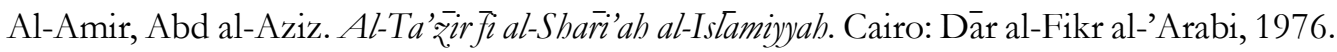


Al-Asmawi, Muhammad Said. Problematika dan Penerapan Syariat Islam dalam Undang-undang.

Terj. Saiful Ibad. Ciputat: Gaung Persada Press, 2005.

Al-Asyqar, Umar Sulaiman. Tǟikh al-Fiqh al-Istami. Kuwait: al-Falāh, 1982.

Atiyyah, Jamal dan Wahbah Al-Zuhaili. Tajdid al-Fiqh al-Islamīi. Beirūt: Dār al-Fikr, 2000.

Attamimi, A. Hamid S., "Kedudukan Kompilasi Hukum Islam dalam Sistem Hukum

Nasional", Amrullah Ahmad, dkk, Dimensi Hukum Islam dalam Sistem Hukum Nasional. Jakarta: Gema Insani Press, 1996.

Al-Awwa, Muhammad Salim. Fi Ușül al-Nižà àm al-Jinā’i al-Istamì. Cairo: Dār al-Ma’ārif, 1983.

Djazuli, A. Kaidah-kaidah Fikih, Kaidah-kaidah Hukum Islam dalam Menyelesaikan Masalah-masalah yang Praktis. Jakarta: Kencana, 2006.

El Fadl, Khaled M. Aboe. Atas Nama Tuhan: Dari Fikih Otoriter ke Fikih Otoritatif. Jakarta: Serambi, 2004.

Ghazali Al-, Abu Hamid Muhammad Ibn Muhammad. Al-Mushtashf̧a min Tlm al-Ușül, Juz I. Beirūt: Dār al-Fikr, t.th.

http://www.antaraaceh.com/2013/11/ulama-aceh-desak-dpra-sahkan-qanun-jinayah.html. Al-Jabiri, Muhammad Abed. Agama Negara dan Penerapan Syariah. Terj. Mujiburrahman. Yogyakarta: Fajar Pustaka Baru, 2001.

Ka’bah, Rifyal. Penegakan Syariat Islam di Indonesia. Jakarta: Khairul Bayan, 2004.

Al-Maliki, Abdurrahman. Sistem Sanksi dalam Islam. Penerj. Syamsuddin Ramadlan. Bogor: Pustaka Thariqul Izzah, 2002.

Musyarrafah, Amiyyah Musmafa, Al-Qāa fi al-Istam. T.tp: Syirkah al-Syarq al-Awsat\}, 1966.

Mutawalli, 'Abdul Hamid. Azmah al-Fiker al-Islami fî al-'Asr al-Hadith. T.tp.: al-Hay'ah alMisriyyah al-'Āmmah li al-Kitāb, 1985.

Al-Naisaburi, Abu Husain Muslim ibn al-Hajjaj ibn Muslim al-Qusyairi. Șạ̣ih Muslim, Juz II. Bairūt: Dār al-Kutub al-'Illmiyyah, t.th.

Ridwan. Muhammad Syahrur: Limitasi Hukum Pidana Islam. Semarang: Walisongo Press, 2008. Sabiq, Al-Sayyid. Fiqh al-Sunnah, Jild. II. Bairūt: Dār al-Fikr, 1983.

Safwat, Safia M. Crime and Punishment under Various School of Shariah: A Comparative Overview, dalam Tahir Mahmood (ed.) Criminal Law in Islam and the Muslim World: A. Comparative Perpective. Delhi: Institute of Objective Studies, 1996.

Sulaiman, Nasruddin, et.al. Aceh: Manusia, Masyarakat, Adat dan Budaya. Aceh: Pusat Dokumentasi dan Informasi, 1992.

Al-Syatibi, Abu Ishaq Ibrahim Ibn Musa. Al-Muwāafaquat fì Ușül al-shā̄i'ah, Juz II. Bairūt: Dār al-Kutub al-'Ilmiyyah, t.th. 
Ijtihad, Jurnal Wacana Hukum Islam dan Kemanusiaan, Volume 14, No. 2, Desember 2014: 149-166

The Wahid Institute. Monthly Report on Religious Issues. Edisi XXIII, Oktober 2009.

Ula, Mutammimul. Perspektif Penerapan Syariat Islam, dalam Penerapan Syariat Islam di Indonesia: Antara Peluang dan Tantangan. Jakarta: Global Media Cipta Publishing, 2004. Yahya, Nasrullah. Konsep Ancaman Pidana Ta'żir: Analisis Pelaksanaan Syari'at Islam dan Upaya Legislasi Hukum Positif Aceh. Medan: La-Tansa Press, 2012.

Zahrah, Abu. Ușül al-Fiqh. Cairo: Dār al-Fikr al-Arābi, t.th.

Zarqa Al-, Musmafa Ahmmad. Al-Madkhal al-Fiqh al-'Ami, Juz II. Damascus: Dār al-Fikr, 1968. 